\title{
TIME SERIES ANALYSIS FOR FORESCASTING THE NUMBER OF TUBERCULOSIS IN KENDARI CITY 2018-2023
}

\author{
La DjaboButon ${ }^{1}$,FitriRachmillah Fadmi ${ }^{2}$ \\ Public Health Studies Program, College of Mandala WaluyaKendari Health Science, Kendari \\ Southeast Sulawesi Province, Indonesia \\ Corresponding Author : Email : ladjabo27@gmail.com
}

\begin{abstract}
ABSTRAK
Tuberculosis is a contagious disease that is still a problem in the world today, not only in developing countries but also in developed countries. That is what happened in Kendari City in 2012 - 2017. Efforts made to prevent the increasing number of tuberculosis in the future is to make predictions. This study aims to study time series analysis in predicting the incidence of tuberculosis based on sex and working area of health centers in Kendari City in 2018-2022. This type of research is quantitative descriptive using the series analysis. Sources of research data obtained from the Kendari City Health Agency in Southeast Sulawesi Province consisted of data on pulmonary TB cases in which sex and working area of Puskesmas in 2012 - 2017 in Kendari City would be processed and analyzed by time series using the trend method into 3 linear trend models, quadratic trends and exponential trends. The results showed the best model for prediction of pulmonary TB cases in Kendari City was the quadratic model. Based on the number of cases predicted to increase in the period 2018 to 2022, with an average decline with an average decrease of 79 cases in men and 286 cases in women. Pulmonary TB cases based on puskesmas area are predicted to increase in 2018 until 2022 with the highest average increase in Kemarayapuskesmas area. While the average decline in cases is highest in the Mata Puskesmas area. It is expected to be able to be information for policy makers, so that prevention and early promotion efforts can be made for the community.
\end{abstract}

Keywords: Tuberculosis, Time, Series, Prediction

\section{INTRODUCTION}

Tuberculosis (TB) is a contagious disease that is still a problem in the world today, not only in developing countries but also in developed countries. The 2016 WHO Global Tuberculosis Report states that Indonesia, with a population of $254,831,222$, ranks second with the highest TB burden in the world. TB in Indonesia is also the number four cause of death after cardiovascular disease $^{(1)}$.Indonesia, through the Ministry of Health has a target of "Indonesia Free TB 2050". To achieve the target of "Indonesia Free TB 2050", community participation is needed, especially in helping to find TB cases and help supervise the treatment of TB patients until healed, so that the chain of TB transmission in Indonesia can be stopped ${ }^{(2)}$.

Tb condition in Southeast Sulawesi Province is also still a health problem. In 2015 in Southeast Sulawesi 3,268 new positive BTA (BTA +) cases were found, slightly lower than in 2014 
with 3,802 cases. As in previous years, the highest reported new cases were still coming from 3 districts namely Muna, Konawe and Kendari City. The number of new cases in the three districts reached $>50 \%$ of the total new cases of BTA + in Southeast Sulawesi. Kendari City in 2015 was ranked second in the highest number of cases in Southeast Sulawesi Province in the last 3 years showing fluctuating data, where the number of new cases of positive AFB smear in 2014 was 549 cases, in 2015 it decreased with the number of cases of 545 cases and then increased in 2016 with 583 cases. This shows that $\mathrm{Tb}$ problem is still a health problem that needs more attention in prevention and overcoming it. One effort that can be done to prevent the increasing number of TB cases in the future is to predict the number of TB cases ${ }^{(3)}$.

Research on prediction is mostly done in the fields of economics and mathematics. However, over time forecasting methods have begun to be used in health research. Some previous studies on forecasting are Research by Andayani, (2016), which uses a straight-line trend analysis method to calculate the prediction of the incidence of pulmonary tuberculosis by age in the district of Ponorogo in 2016-2020. Then Susanto, et al (2015), who used time series analysis to predict the number of Tuberculosis cases in 2010-2014 and obtained results that Tb cases will continue to increase. This study aims to determine the time series analysis in predicting the incidence of new pulmonary tuberculosis (+) in Kendari City in $2017-2021^{(4),(5)}$.

\section{METHODE}

The type of research in this research is descriptive quantitative with the design of times series analysis, namely by describing the frequency of the disease based on a series of observations in several time sequences. The source of the research data was obtained from the Kendari City Health Institution of Southeast Sulawesi Province, which is the data of the new Tb BTA $(+)$ case, which included the gender and working area of the Puskesmas in $2012-2017$ in Kendari City. The dependent variable is the new Tb BTA (+) case. While the independent variables include gender, Puskesmas working area and time.

Data processing in this study uses the Microsoft Excel program. While the data analysis in this study uses time series analysis with the trend method approach (linear trend, quadratic trend and exponential trend). After the data is analyzed into the 3 models, we will then see the value of R. square (coefficient of determination), MAE (average value of prediction error) and MAPE (percentage value of prediction error) obtained. The greater the value of R. square obtained, the better the trend model is to predict an event, and the smaller the product of the MAE and MAPE values, the more accurate the model is to predict an event.

\section{RESULT}

The number of new smear TB cases (+) based on sex in Kendari City in 2018-2021 can be seen in Figure 1 below. 


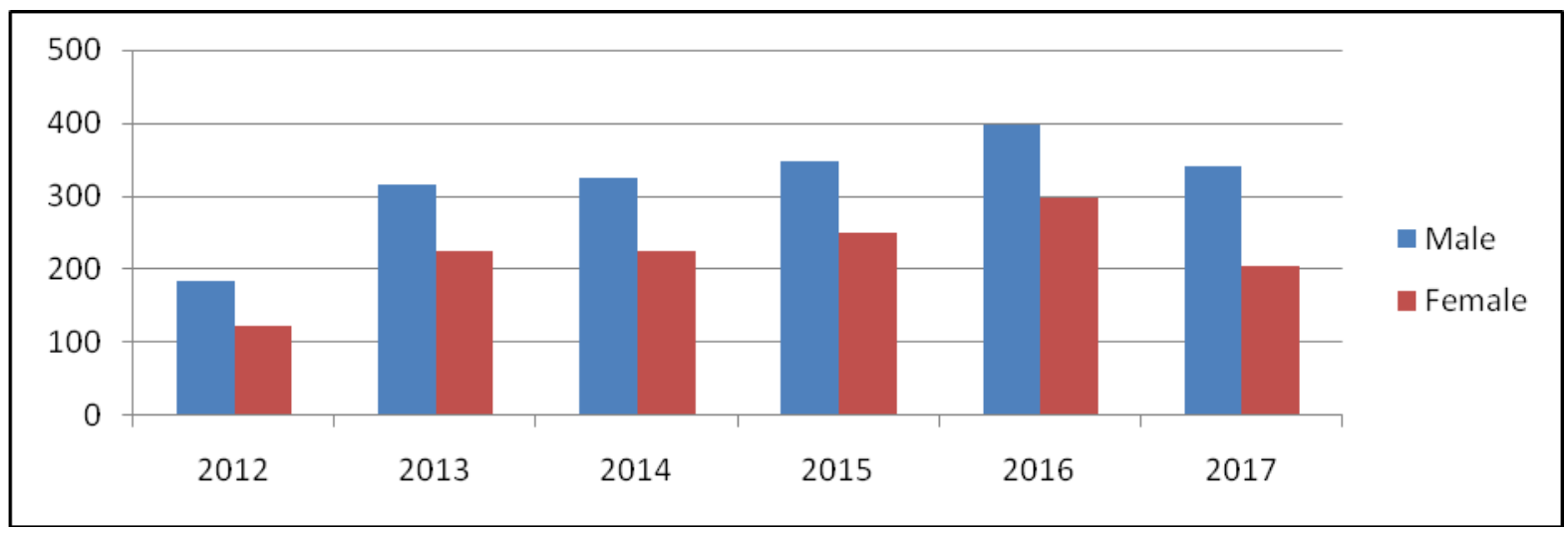

Figure 1. Number of New BTA Lung TB Cases (+) by Gender in Kendari City

Figure 1 shows that the highest number of tuberculosis by sex, both men and women in 2012 - 2017 was in 2016 with 398 cases in men and 297 cases in women. The number of new cases of pulmonary tuberculosis is more in males than females.

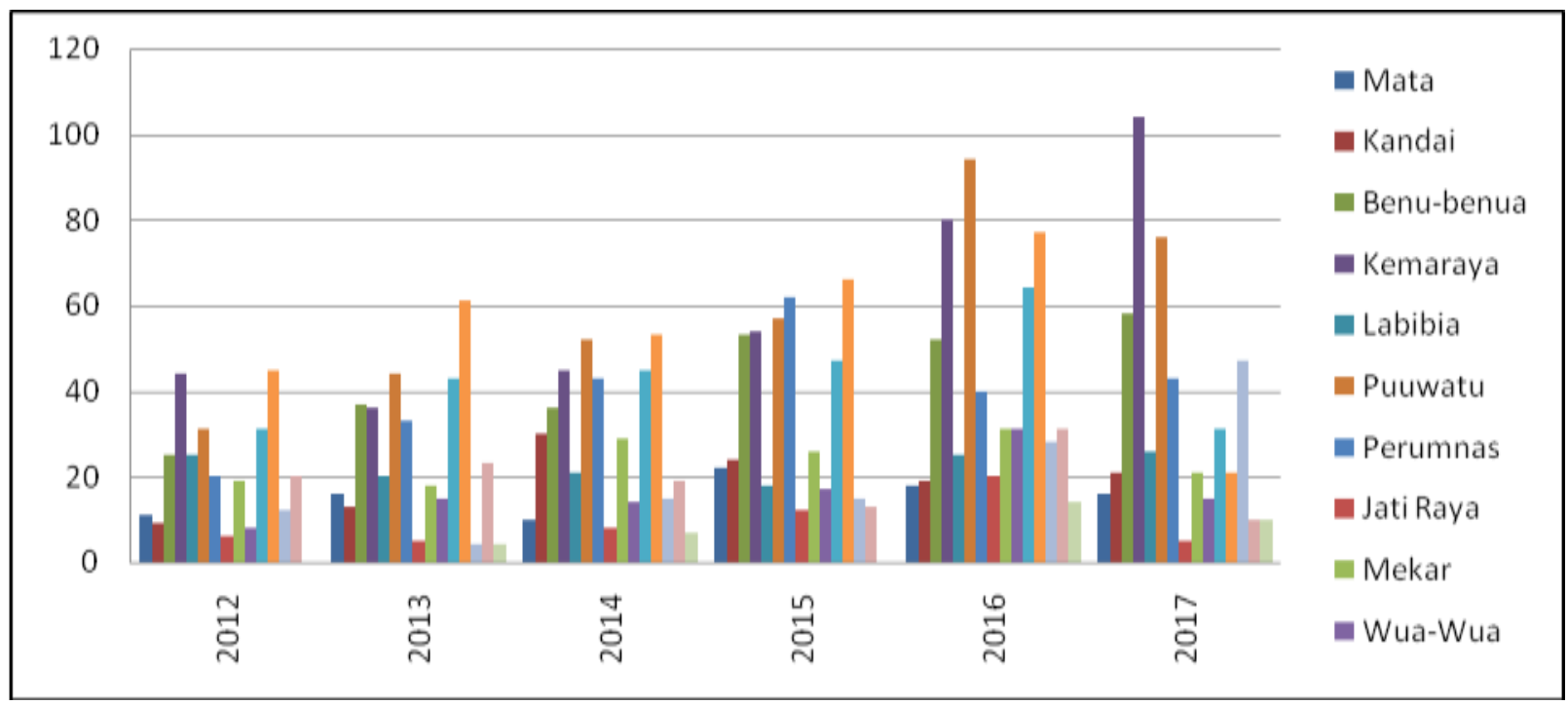

Figure 2. Number of tuberculosis based Health Centre Working Area in Kendari City

Figure 2 shows the number of tuberculosis based on regions in 2012-2017. The highest number of cases in 2012 to 2015 were in the Poasia Health Center working area with 45 cases in 2012, in 2013 as many as 61 cases, in 2014 there were 53 cases and in 201566 cases. While the highest number of cases in 2016 were in the Puuwatu Health Center with 95 cases and the highest number of cases in 2017 were in the Kemaraya Community Health Center with 104 cases. Then an analysis is performed to see the value of $R$ Square. The greater the value of R. square obtained, the better the trend model to predict an event. The results of $R$ Square can be seen in table 1.

Table 1. R Square results for the selection of time series analysis of the Trend method

\begin{tabular}{|l|c|c|c|}
\hline \multirow{2}{*}{ Variable } & \multicolumn{3}{|c|}{$R$ Square } \\
\cline { 2 - 4 } & Mode 1 & Model 2 & Model 3 \\
\hline Sex & & & \\
\hline
\end{tabular}




\begin{tabular}{|c|l|l|l|}
\hline Male & 0,363 & $\mathbf{0 , 8 0 8}$ & 0,388 \\
\hline Female & 0,504 & $\mathbf{0 , 8 6 2}$ & 0,504 \\
\hline Health Centre & \multicolumn{3}{|l|}{} \\
\hline Mata & 0.265 & $\mathbf{0 . 3 5 3}$ & 0.289 \\
\hline Kandai & 0.260 & $\mathbf{0 . 6 6 0}$ & 0.396 \\
\hline Benu-Benua & 0.905 & $\mathbf{0 . 9 1 8}$ & 0.878 \\
\hline Kemaraya & 0.811 & $\mathbf{0 . 9 9 1}$ & 0.832 \\
\hline Labibia & 0.077 & $\mathbf{0 . 7 2 6}$ & 0.065 \\
\hline Puuwatu & 0.801 & $\mathbf{0 . 8 6 6}$ & 0.808 \\
\hline Perumnas & 0.361 & $\mathbf{0 . 7 5 8}$ & 0.461 \\
\hline Jati Raya & 0.161 & $\mathbf{0 . 3 3 5}$ & 0.125 \\
\hline Mekar & 0.204 & $\mathbf{0 . 5 8 7}$ & 0.225 \\
\hline Wua-Wua & 0.360 & $\mathbf{0 . 4 8 3}$ & 0.463 \\
\hline Lepo-Lepo & 0.081 & $\mathbf{0 . 5 1 4}$ & 0.058 \\
\hline Poasia & 0.026 & $\mathbf{0 . 5 3 4}$ & 0.112 \\
\hline Mokoau & 0.750 & $\mathbf{0 . 9 5 9}$ & 0.658 \\
\hline Abeli & 0.053 & $\mathbf{0 . 1 5 1}$ & 0.097 \\
\hline Nambo & 0.485 & $\mathbf{0 . 4 8 7}$ & - \\
\hline
\end{tabular}

The results of $\mathrm{R}$ Square on the selection of the time series analysis of the Trend method on the case of tuberculosis sex indicate that the largest percentage of R-Square in both male and female sexes is in model 2 namely quadratic. Thus a suitable model is used to predict the number of cases of pulmonary TB based on the sex of both men and women in the period 2018 to 2022 is a quadratic model. Thus the results of $R$ Square on the selection of time series analysis of the Trend method for TB cases based on the puskesmas area showed that the largest R-Square percentage was in the quadratic model.

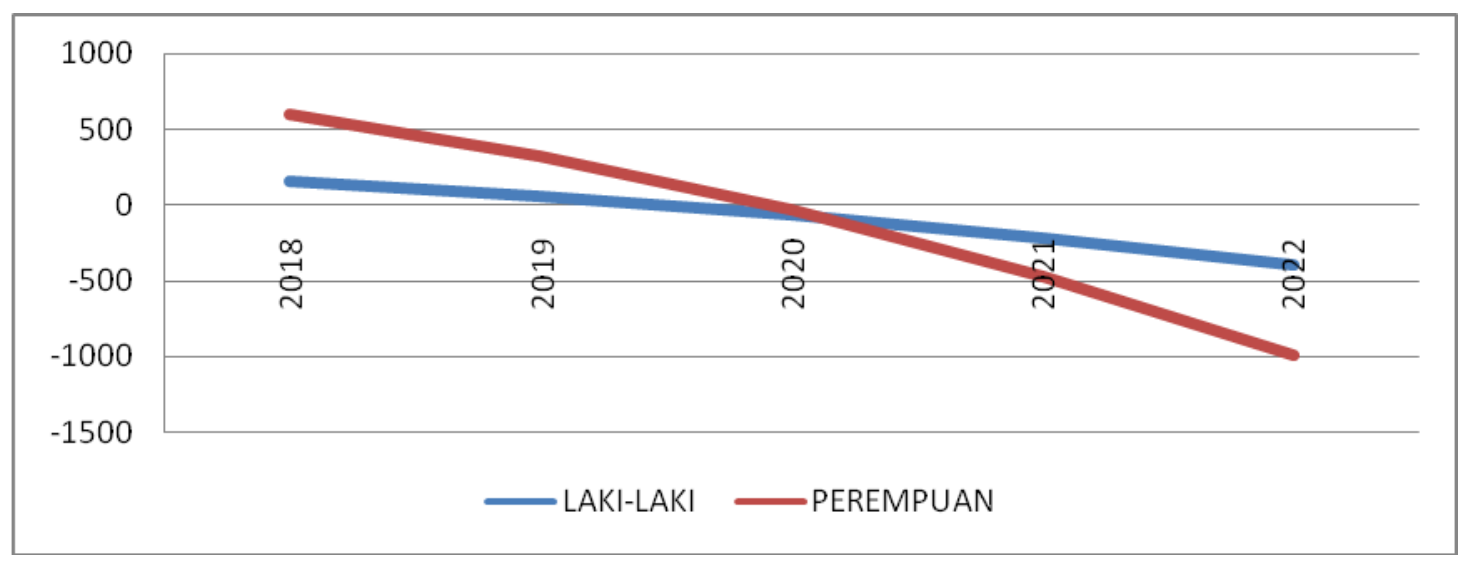

Figure 3. Quadratic Model Trend The number of tuberculosis is basedGender in Kendari City

Based on the results of the time series analysis with the trend method, to calculate the prediction of AFB cases of tuberculosis by sex using the quadratic equation model, shows that in 2012 to 2017 new AFB cases of tuberculosis both in male and female sex women tend to fluctuate 
with cases that increased in 2012 to 2015 and began to decline in 2016 to 2017. After the prediction of AFB Lung TB cases (+) using a quadratic equation model both in male and female sex shows the number of cases that will continue decreased until 2022, with an average decrease of 79 cases in men and 286 cases in women.

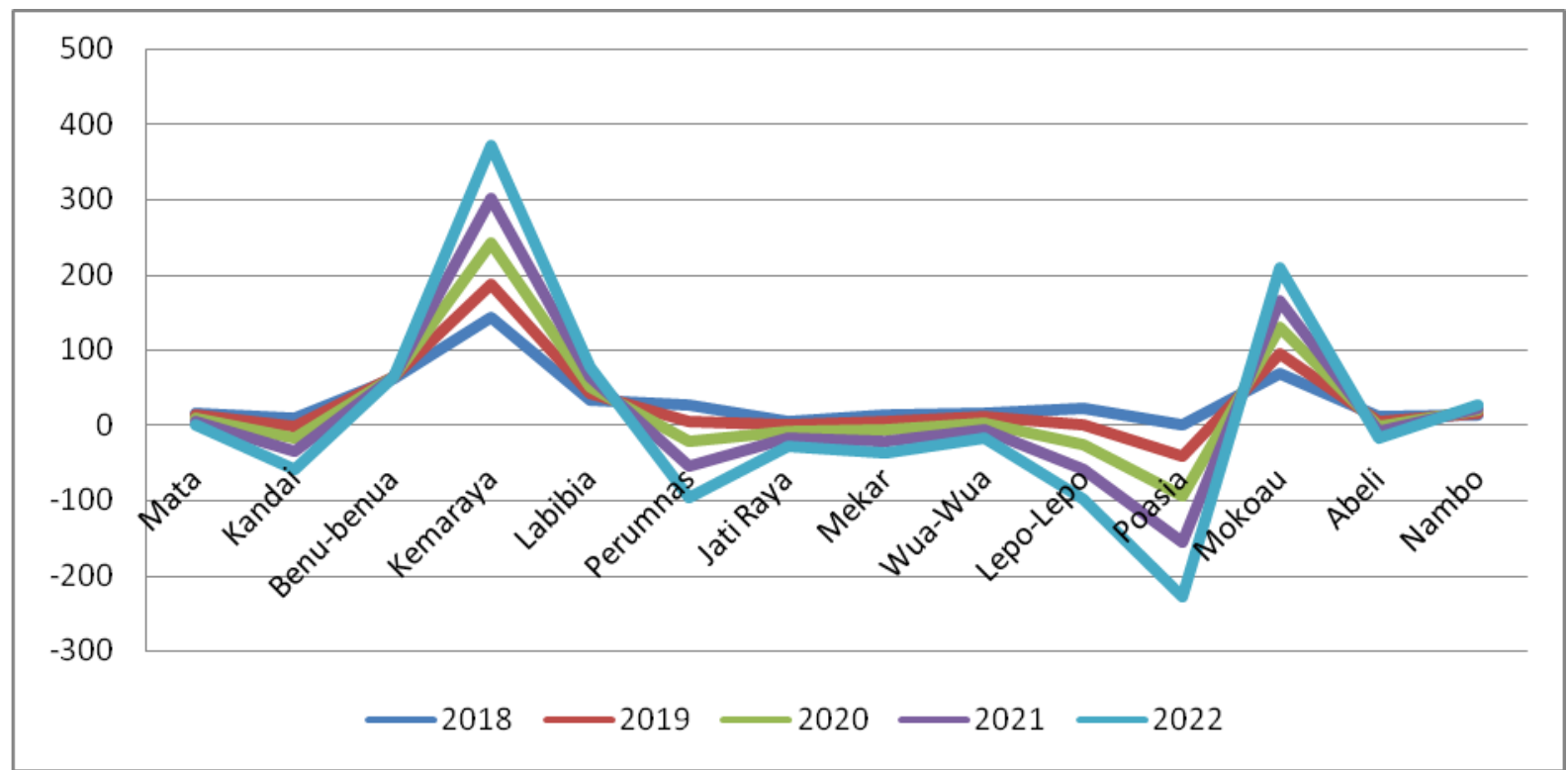

Figure 4. Quadratic Model Trend The number of tuberculosis based on the Puskesmas area in the city of Kendari

Figure 4 shows that from the results of the time series analysis using the trend method, to calculate the prediction of tuberculosis in the work area of the puskesmas using quadratic equations, 4 puskesmas work areas will experience an increase in cases by 2022 with an average increase of 146 cases for the Kemarayapuskesmas area, 77 cases for the Labibiapuskesmas area, 77 cases for the puuawatupuskesmas area 72 cases for the Mokoaupuskesmas area and 12 cases for the Nambopuskesmas area. While those who experienced a decrease of 9 regions with an average reduction of cases were 12 cases of the Mata Puskesmas Region, 1 case of the KandaiPuskesmas Region, 53 cases in the Benu-continent Puskesmas, 9 cases in the PerumnasPuskesmas, 1 case in the Jati Raya Puskesmas, 8 Cases in the PuskesmasMekarPuskesmas, 10 Cases for Wua-wuaPuskesmas, 9 Lepo-lepoPuskesmas, -18 cases for PoasiaPuskesmas, and 9 cases for AbeliPuskesmas.

\section{DISCUSSION}

Sex is one of the significant determinants in health events or in risk factors for a disease. The prevalence of tuberculosis in Indonesia in men is two times greater than in women. The Indonesian Ministry of Health reports that men suffer more pulmonary tuberculosis than women. Few women have smoking habits. Smoking can cause impaired ciliary function in the respiratory tract thereby increasing the risk of becoming infected with tuberculosis. Worldwide, TB cases among those exceeded are found in women, with a male to female ratio of 1.7: 1.1. This average 
hides substantial heterogeneity between countries, but despite this marked variation, sex has received inadequate attention in TB disease research and control programs ${ }^{(6)}$.

The results showed that the highest number of new cases of pulmonary tuberculosis by sex both men and women in 2012 - 2017 were in 2016 and then simultaneously dropped in 2017 which was dominated by male sex. Thus the results of predictions for 2018-2022 show that new cases of pulmonary tuberculosis from both male and female sex will continue to decline with the highest number of cases in male sex. The results of this study are in line with research Similar results were also stated by previous researchers that the results of forecasting (forecasting) showed the number of pulmonary TB morbidity based on male sex from year to year is the highest case $^{(7)}$. Other results show that more cases are reported among men than women, so when grouped into the same age group, women dominate at the age of 15-24 years (ratio of men to women $0.84^{(8)}$.

Male gender Lung TB disease is more prone to suffer from pulmonary tuberculosis than in women because of the habit of men because men have high mobility than women so the possibility of exposure is greater, besides the habit of frequent smoking and consuming alcoholic drinks which can decrease body's defense system. So it is natural that smokers and alcohol drinkers are often referred to as agents of pulmonary TB disease ${ }^{(9)}$. Mycobacterium tuberculosis which is a bacterium that causes TB can attack both men and women. From the results of the study for the number of TB sufferers by sex, the number of TB sufferers in men is higher than for women, with 2,638 male TB sufferers and 1,628 female TB sufferers, whereas the number of male population is less than women. Forecasting results obtained are also higher in men than women ${ }^{(10)}$. The vulnerability of men to TB infection is based on the high daily mobilization of men so that they are easily exposed to air contaminated with TB bacteria, not because of low economic levels. Whereas in general, people with TB come from poor families ${ }^{(11)}$.

The number and distribution of population in a Puskesmas working area will determine the number of sufferers registered in the Puskesmas. The number and distribution of population determines population density in an area. Population density in addition to determining how quickly the disease can spread, whether or not many sufferers if sudden changes occur such as extraordinary events and the size of the place of adequate health care. Areas with high population density tend to have slum dwellings, poor hygiene and nutrition, so that if there are citizens affected by TB disease will accelerate the spread process ${ }^{(12)}$.

Kendari City is the capital of Southeast Sulawesi Province which has a land topography with mountainous, bumpy and hilly surfaces. Between the mountains and hills, the plains of fertile agriculture and plantations lay. Cultural diversity and customs with different characteristics from one another based on geographical location, the diversity in various aspects also affects people's behavior towards health ${ }^{(13)}$. Characteristics that differ from one another based on geographical location so that it can affect people's behavior towards health ${ }^{(14)}$.

The number and distribution of population in an area will also determine the number of sufferers. The number and distribution of population determines population density in an area. Population density in addition to determining how quickly the disease can spread, whether or not many sufferers if sudden changes occur such as extraordinary events and the size of the place of adequate health care. Areas with high population density tend to have slum dwellings, hygiene, poor nutrition, causing many poor families. The increase of poor families will make it difficult to 
fulfill the nutritional requirements so that it can cause malnutrition. Malnutrition will cause the immune system to be more vulnerable so it is easily exposed to disease agents ${ }^{(15)}$.

\section{CONCLUSION}

1. The best model for prediction of pulmonary TB cases in Kendari City is the quadratic model

2. Lung TB cases by sex are predicted to decrease in the period 2018 to 2022, with an average decline with an average decline of 79 cases in men and 286 cases in women.

3. Pulmonary TB cases based on puskesmas area are predicted to experience an increase in cases from 2018 to 2022 with the highest average increase being in the Kemarayapuskesmas area. While the highest average decrease in cases in the Eye Health Center area.

\section{REFERENCES}

1. Organization WH. WHO treatment guidelines for drug-resistant tuberculosis: World Health Organization; 2016.

2. KeMenKes R. Profil kesehatan Indonesia tahun 2015. Jakarta Kementeri Kesehat Republik Indones. 2016.

3. Kendari DKK. Profil Dinas Kesehatan Kota Kendari. 2016.

4. Andayani S, Astuti Y. PREDIKSI KEJADIAN PENYAKIT TUBERKULOSIS PARU BERDASARKAN USIA DI KABUPATEN PONOROGO TAHUN 2016-2020. Indonesian Journal for Health Sciences. 2017;1(2):29-33.

5. Susanto HA, Sakka A, Tina L. Prediksi kejadian penyakit Tb Paru BTA positif di Kota Kendari tahun 2016-2020. Jurnal Ilmiah Mahasiswa Kesehatan Masyarakat. 2016;1(2).

6. Getahun H, Matteelli A, Abubakar I, Aziz MA, Baddeley A, Barreira D, et al. Management of latent Mycobacterium tuberculosis infection: WHO guidelines for low tuberculosis burden countries. European Respiratory Journal. 2015;46(6):1563-76.

7. Pujianti TM, Damayanti D, Erawantini F. Perencanaan Kebutuhan Tempat Tidur di Rumah Sakit Paru Jember Tahun 2013-2015. Jurnal Manajemen Informasi Kesehatan Indonesia (JMIKI). 2014;2(1).

8. Khaliq A, Batool SA, Chaudhry MN. Seasonality and trend analysis of tuberculosis in Lahore, Pakistan from 2006 to 2013. Journal of epidemiology and global health. 2015;5(4):397-403.

9. Reniers G, Blom S, Lieber J, Herbst AJ, Calvert C, Bor J, et al. Tuberculosis mortality and the male survival deficit in rural South Africa: An observational community cohort study. PloS one. 2017;12(10):e0185692.

10. Lubis LA. Trend Analisis dengan Metode Time Series untuk Meramalkan Penderita Tuberkulosis (TB) Tahun 2017-2021 berdasarkan Data Penderita TB Tahun 2012-2016 di Kabupaten Mandailing Natal. 2018.

11. Dotulong J, Sapulete MR, Kandou GD. Hubungan Faktor Risiko Umur, Jenis Kelamin dan Kepadatan Hunian dengan Kejadian Penyakit TB Paru di Desa Wori Kecamatan Wori. Jurnal Kedokteran Komunitas dan Tropik. 2015;3(2).

12. 12. Bam TS, Aditama TY, Chiang C-Y, Rubaeah R, Suhaemi A. Smoking cessation and smokefree environments for tuberculosis patients in Indonesia-a cohort study. BMC Public Health. 2015;15(1):604. 
13. 13. Tenggara DKPS. Profil Kesehatan Provinsi Sulawesi Tenggara Tahun 2015. Kendari: Dinas Kesehatan Provinsi Sulawesi Tenggara. 2016.

14. 14. Fadmi FR, Mulyani S, Buton LD. Geographically Weighted Regression (GWR) Approach in the Modeling of Malnutrition and the Influencing Factors in Muna Regency. Indian Journal of Public Health Research \& Development. 2018;9(6).

15. 15. Bhandari TR. Maternal and child health situation in South East Asia. Nepal Journal of Obstetrics and Gynaecology. 2012;7(1):5-10. 